Scop: A Retrospective (2002-2008)

\title{
Stephanie McKenzie*
}

I incorporated Scop Productions Inc. in Corner Brook, NL, in 2002. The name of the company, Scop (pronounced shōp), is the Old English/Anglo-Saxon word for wandering poet, and the name turned out to be an appropriate choice as Scop engaged in international activities. Although mainly a publishing house, Scop was also conceived in a broader sense as a production company, so that I could engage in any aspect of promoting the arts - both inside and outside of Canada.

Scop's first publication was a slim anthology, Humber Mouths: Young Voices from the West Coast of Newfoundland \& Labrador (2002), and when the poets included in this anthology travelled the 700 kilometres to St John's to launch the book at the Ship Inn, we made municipal, provincial, and national news. In a recent article I provided the following background information on the significance of this publication. ${ }^{\text {I }}$ From 1998, I ran a creative writing group with Al Pittman who was perhaps the most significant "people's poet" of Newfoundland. We also created together a local talent festival, The April Rabbit, following in the footsteps of The March Hare (Atlantic Canada's largest festival of words and music), where emerging poets and musicians could showcase their talent each April in Corner Brook.

* Stephanie McKenzie is an Assistant Professor in the Department of English, Sir Wilfred Grenfell College (Memorial University of Newfoundland). She is the author of Before the Country: Native Renaissance, Canadian Mythology (University of Toronto Press, 2007) and two collections of poetry, Cutting My Mother's Hair (2006) and Grace Must Wander (2009), both published by Salmon Poetry, Cliffs of Moher, Ireland.

I Stephanie McKenzie, "Some Reflections on Writing Poetry and Publishing in Canada," in Poetry: Reading It, Writing It, Publishing It, ed. Jessie Lendennie (Cliffs of Moher: Salmon Poetry, 2009), I09-IIo.

2 Martin Ware, "Introduction," in An Island in the Sky: Selected Poetry of Al Pittman (St John's: breakwater Books, 2003), 8. Ware maintains that Pittman (1940-200I) "thought that to aspire to be a poet was to aspire to a role which was the treasure of the world, that the poet's influence was vital to the life of a healthy community, and that it was natural for people to honour and enjoy poetry and song" (I3). 
When Al Pittman died in 200I, our writing group began thinking about publishing something in his honour: "One member of the writing group suggested we should put out a [special] photocopied version of the group's work ... We were all getting excited, and I suggested that instead of just a fancy photocopy we could perhaps produce something that looked like a book. Now even more excited, someone said to me, 'What's the difference between something that looks like a book and a book?' That was it. I thought of a company name - Scop Productions - found a local printer, garnered a small amount of funding at [Sir Wilfred Grenfell College] and began compiling the first edition of Humber Mouths."

This was the beginning of a significant amount of company activity. Unwittingly at first, Scop was poised for international endeavours due to a memorandum of understanding between the Irish and Newfoundland governments (signed in 1996 and reaffirmed in 1999 and 2004) which aimed to foster, amongst many other things, international cultural arts initiatives. In 2003, Scop co-published (with the Centre for Newfoundland \& Labrador Studies, School of Humanities, Waterford Institute of Technology [WIT], Waterford, Ireland) The Backyards of Heaven: An Anthology of Contemporary Poetry from Ireland and Newfoundland \& Labrador, and, in 2004, However Blow the Winds: An Anthology of Poetry and Song from Newfoundland \& Labrador and Ireland. In 2006, Scop also published Irish poet John Ennis's collection Goldcrest Falling and co-published, with the School of Humanities, WIT, Living at the Edge, Living at the Centre: Vivre en marge, vivre au seuil des possibilités, a collection of conference proceedings from a Francophone / Newfoundland / Irish conference held at WIT in 2003.

Scop's mandate was to promote and encourage voices and other forms of art from the west coast of Newfoundland and Labrador. For example, I commissioned visual artist Rodney Mercer, whose painting provided the cover illustration for Humber Mouths (Figure I), to produce a portrait of Al Pittman for the second edition, as well as a drawing to preface that book of poetry. Scop sold a number of then Corner Brook-based artist Michael Pittman's artworks, as well as works by other young local artists - Matthew Hollett, Melissa Martin, and David Gale - to WIT. ${ }^{3}$ These remain on display in

3 For a brief overview of the history of The Backyards of Heaven and to view photos of the artworks, see Stephanie McKenzie, "New Directions in Poetry and Art," Newfoundland Quarterly 96, no. I (Spring 2003): 24-27. 

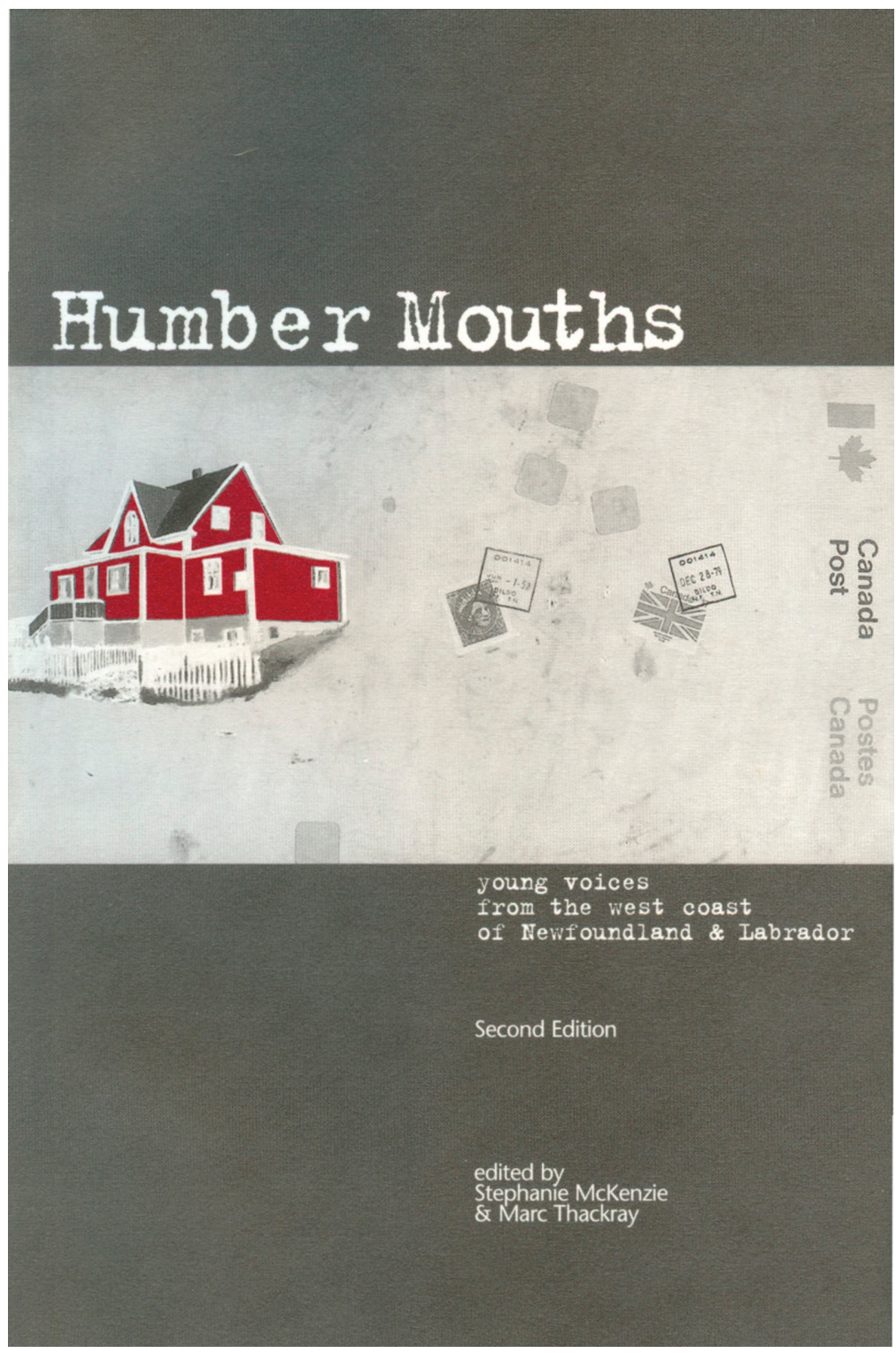

Figure I: Cover of Humber Mouths (2nd ed.) with illustration by Rodney Mercer. 
Ireland. When Newfoundland and Labrador Premier Danny Williams visited Ireland and the Centre for Newfoundland \& Labrador Studies at WIT in 2004, I also commissioned artists to create portraits of all the premiers who had been in power in the province since the signing of the first memorandum of understanding between the governments of Newfoundland \& Labrador and Ireland. Of particular importance was the portrait Rodney Mercer created of Premier Williams, a copy of which was given to the premier as a gift. Mercer's portrait of Craig Dobbin, co-founder of the Ireland Canada University Foundation, was also given by Scop to Dobbin for his seventieth birthday. ${ }^{4} \mathrm{~A}$ well-known patron of various individuals and arts organizations over the years, Dobbin had supported Scop's The Backyards of Heaven, enabling the company to finance a significant amount of the monies needed to bring the Newfoundland poets to Ireland for the book's launch in Waterford, Dublin, Belfast, Galway, and Cork in 2003. Scop also produced a number of music shows at Humber Valley Resort, near Corner Brook, in 2005, bringing some of Newfoundland's best musical talents to the coast to perform not only for local audiences but also visitors from abroad who were staying at the resort. David Maggs and Friends (classical quartet) performed July I5, followed by the renowned folk musicians Pamela Morgan (August I2), Ron Hynes (August 19), and Fergus O’Byrne and Jim Payne (September 2).

When a significant number of west coast artists won awards in Newfoundland and Labrador's Arts and Letters Competition in 2005, Scop threw a party for those artists who could not travel to St John's to receive their awards (there is no funding for such travel). The first arts awards ceremony to be held on the west coast, "A Celebration of West Coast Achievements in the Arts and Letters" took place 9 June 2005 at Humber Valley Resort. Scop organized and emceed the event, which was supported by funding solicited from the Premier's Office; the Newfoundland \& Labrador Department of Tourism, Culture and Recreation; Sir Wilfred Grenfell College, Memorial University of Newfoundland; Air Labrador; and ten local businesses.

In 2006, when Irish poet Paul Muldoon was awarded an honorary doctor of letters degree at Sir Wilfred Grenfell College's convocation and a dinner was held in his honour, Scop Productions was hired

4 Dobbin (1935-2006), CEO of Canadian Helicopter Corporation, traced his ancestry back to county Waterford. Among his many accomplishments was the establishment of the Craig Dobbin Professorship of Canadian Studies at University College Dublin in 1994. 
to provide entertainment. The audience may have expected a poetry reading or musical affair, but Scop arranged a fashion show where models boasted the local designs of eight west coast textile artists and designers. The show included babies who modelled the infant clothing designs of Corner Brook artist Shawn O'Hagan. Though such activity might seem outside the purview of book history, it highlights what Scop was about: fostering ties between artists of all sorts and engaging in artistic "bartering." Interconnections between a variety of artists and arts organizations are essential to book publishing, especially for a company which has just begun. To create books, one must have the help of graphic designers, software experts, financial advisors or accountants, and editors, as well as - when it comes time to promoting and launching works - entertainment artists. Over the years Scop had the help of many individuals who benefited, in turn, by gaining publicity for their work. This fashion show, for example, gave the artists some exposure to publicize their wares and hopefully gain sales. And, while it boasted clothes and not books, it also served to attract media attention for Scop, adding to the company's profile which could then be used to legitimize requests for funding. In essence, Scop was driven by the belief that artists could only survive and thrive if they supported one another.

Scop's activities have been varied, and it is not possible to outline everything here (such as the arrangements of book launches, media tracking, fundraising campaigns, and much more). What can be said, though, is that much of Scop's success was, and is, attributable to Michael Pittman (nephew of Al Pittman and an award-winning artist), who functioned for a number of years as vice-president of the company, who created and maintained Scop's website, and who designed graphics (including business cards and promotional materials), as well as the t-shirts which Scop sold for a short period of time. Pittman also modified the original drawing of "the dish and the spoon" which Rodney Mercer had created for Humber Mouths, to create what became the company's logo. Pittman also did much much more along the way.

Scop was launched when there was no provincial funding in Newfoundland and Labrador for publishing houses, and funding from the national sponsors, Canadian Heritage and the Canada Council for the Arts, was impossible to secure for yet-to-be established presses. There had been funding for publishers in the province in the 1980s and early I990s which was eliminated in 1996. It was only in 2006 that the Publishers Assistance Program, now under the auspices of the 
Department of Tourism, Culture and Recreation, was resurrected, so Scop did not have at its disposal any secure funding options during its first critical years.

Scop is now gone, folded. But I have learned valuable lessons. Try to convince people of the value of the arts. Pay time and particular attention to young and emerging voices and visions: Culture is carried on by the younger generation, as well as by those who have learned from the arts over the years. When people and institutions put up roadblocks in front of the arts, challenge them.

So, yes, though Scop is no more, a lot was achieved in five years. And a lot more can be achieved. Though bards wander, they are predictable and can't help but performing.

\section{Publications by Scop}

McKenzie, Stephanie, ed. Humber Mouths: Young Voices from the West Coast of Newfoundland \& Labrador. Corner Brook, NL: Scop Productions, 2002.

McKenzie, Stephanie, and Marc Thackray, eds. Humber Mouths: Young Voices from the West Coast of Newfoundland \& Labrador. 2nd ed. Corner Brook, NL: Scop Productions Inc., 2002.

McKenzie, Stephanie, and John Ennis, eds. The Backyards of Heaven: An Anthology of Contemporary Poetry from Ireland and Newfoundland \& Labrador. Corner Brook, NL, and Waterford, Ireland: Scop Productions Inc. and School of Humanities Publications, Centre for Newfoundland \& Labrador Studies, Waterford Institute of Technology, 2003.

Ennis, John, Randall Maggs, and Stephanie McKenzie, eds. However Blow the Winds: An Anthology of Poetry and Song from Newfoundland \& Labrador and Ireland. Corner Brook, NL, and Waterford, Ireland: Scop Productions Inc. and Centre for Newfoundland \& Labrador Studies, Waterford Institute of Technology, 2004.

Ennis, John. Goldcrest Falling. Corner Brook, NL: Scop Productions Inc., 2006.

McKenzie, Stephanie, Christine O'Dowd-Smyth, and Marc Thackray, eds. Living at the Edge, Living at the Centre: Ireland, Newfoundland, the Francophone World: The Birth of a New, Demarginalised Creativity/ Vivre en marge, vivre au seuil des possibilités: la Francophonie, l'Irlande, 
Terre-Neuve: naissance d'une expression démarginalisée. Waterford, Ireland, and Corner Brook, NL: Centre for Newfoundland \& Labrador Studies, School of Humanities, Waterford Institute of Technology, and Scop Productions Inc., 2006.

\section{SOMMAIRE}

Fondée en vue d'honorer en partie l'héritage d'Al Pittman, «le barde du peuple», et s'avérant être moitié maison d'édition et moitié maison de production, la firme Scop Productions dont le siège est à Corner Brook s'est engagée dans des initiatives en lien avec les arts d'agrément multidisciplinaires et ce, à l'échelle internationale. Cette étude relate la création de la compagnie, ses activités à Terre-Neuve et en Irlande, sa recherche de financement tout en soulignant l'importance de Scop auprès des artistes et des communautés. 
